\title{
Symposium review: The impact of management and facilities on cow culling rates*
}

\author{
N. B. Cook† (i) \\ School of Veterinary Medicine, University of Wisconsin, Madison 53706
}

\begin{abstract}
This symposium review examines the association between comfort and cow longevity, with a particular emphasis on optimizing resting behavior in confinementhoused systems. Housed dairy cattle demonstrate a variety of negative behavioral and physiological effects when lying time is restricted, with cows prioritizing the recovery of rest over feeding when both are deprived. There is, however, wide individual-cow variation in daily lying times, influenced by an array of cow-, housing-, and management-related factors. Cow-related factors include individual preference, parity, stage of lactation cycle, milk yield, ill health, and lameness. Lying time tends to increase with age and days in milk and during periods of ill health, whereas milk yield is negatively correlated with lying time. The effect of lameness is complicated by severity and by interactions with bedding type, which modifies the cows' ability to rise and lie down. Generally, lame cows suffer prolonged lying bouts of greater variability in length and take fewer bouts per day. Often this results in an overall increase in lying time. Thus, higher standards of cow comfort and improved cow health are not always reflected by longer lying times. Housing and management factors that influence resting behavior include the design of the resting area, access to the resting space, and the thermal microenvironment of the lying area. Provision of dry, deep loose bedding, stocking cows to allow each animal access to a resting space, allowing sufficient time to access the resting area, and providing heat abatement to reduce heat load optimize resting behavior. Because lameness and poor body condition are commonly found in culled dairy cattle, the link between cow comfort and culling is likely mediated through lameness onset and management. Optimal comfort helps prevent the
\end{abstract}

\footnotetext{
Received June 22, 2019.

Accepted October 15, 2019.

*Presented as part of the Southern Section Symposium: Dairy Cattle Longevity Revisited-Trends, Economics, and Opportunities at the ADSA Annual Meeting, Cincinnati, Ohio, June 2019.

†Corresponding author: nigel.cook@wisc.edu
}

onset of lameness and facilitates recovery once cows become lame, which limits the effect of lameness on feeding behavior and reduces the risk for other healthrelated disorders, poor reproductive performance, and early herd removal. Cow comfort cannot be assessed by measuring the duration of lying time alone. Rather, comfort is reflected by the optimization of resting behavior, providing facilities and management to allow cows to lie down when they choose to do so for as long as they need to.

Key words: longevity, optimal resting behavior, lying time, lameness

\section{INTRODUCTION}

An individual dairy cow's productive life in the herd is determined by her health and fertility and the economic need for dairy producers to optimize the milk production of each individual within the herd, for a duration determined by replacement availability. To that end, several aspects of management and facility design affect the health and longevity of the cow while she remains in the herd, which we often collectively refer to using the term "cow comfort." Merriam-Webster provides several definitions for the noun "comfort," but perhaps the most suitable to the needs of the cow is "contented well-being," emphasizing that comfort encompasses both physical and emotional wellness. Many aspects of a cow's life contribute to her comfort (see Figure 1). This includes her ability to walk and exercise freely without risk of injury, gain access to sufficient food and water to satiate her hunger and thirst, seek shelter from weather and climate extremes, and, perhaps most important, a desire to achieve adequate rest. In this symposium review, I use the term "rest" to encompass all aspects of lying behavior, including lying time, lying bout duration, and number of lying bouts taken each day. Although the importance of optimizing feeding behavior and its potential effects on health have been well reviewed (e.g., DeVries, 2019), the association between the resting component of cow comfort and longevity has received less attention despite the increasing number of reports using data loggers capable 


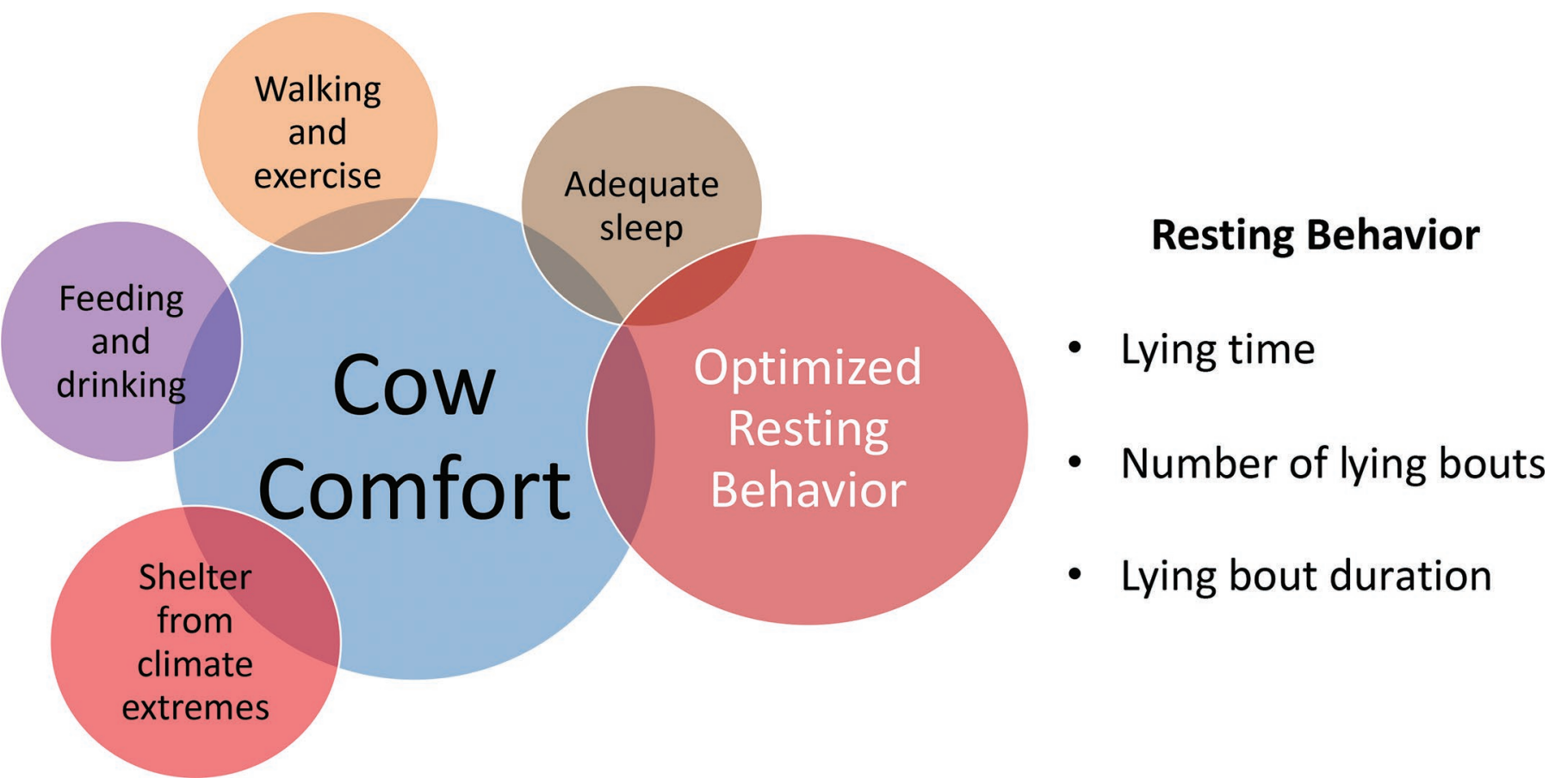

Figure 1. Components of cow comfort.

of measuring lying behavior on large numbers of cows in a commercial setting (Ledgerwood et al., 2010). This review describes our current knowledge regarding the effect of restricting lying time, summarizes the cowrelated and housing- and management-related factors that influence intra- and interherd variation in resting behavior, and describes the potential role cow comfort plays in reducing the risk for early herd removal in housed dairy cattle.

The literature was searched using keywords including bovine, cow, dairy, housing, lying time, sleep, lameness, behavior, culling, turnover, and longevity using Google Scholar and Web of Science databases for the period from January 2000 to June 2019. Other pertinent literature was identified by backward search from references of the papers found. The literature cited serves to substantiate the opinions expressed.

\section{EFFECTS OF LYING DEPRIVATION AND OPTIMAL RESTING BEHAVIOR}

Deprivation studies of housed cattle show that cows are negatively affected by relatively short periods of reduced lying time. Using a reward duration methodology, where lying-deprived pregnant dairy heifers were required to press against a panel to gain access to lying, Jensen et al. (2005) demonstrated an inelastic demand for 12 to $13 \mathrm{~h}$ of rest/d. By limiting access to a resource pen that provided lactating dairy cows access to a place to lie down, eat, or socialize, Munksgaard et al. (2005) showed that the proportion of time lying down increased in the pen relative to other behaviors, suggesting that the cows placed a higher priority on lying down. After a 2- to 4-h lying deprivation, housed cows showed increased leg stomping, weight shifting, and head swinging and ruminated less while standing. During the immediate recovery period, cows with only $2 \mathrm{~h}$ of lying deprivation failed to fully compensate for the lost time over the ensuing $40 \mathrm{~h}$ (Cooper et al., 2007). Similarly, Metz (1985) deprived lactating cows of both lying and feeding for $3 \mathrm{~h}$ and showed that afterward, cows preferred to spend time lying rather than eating, with the authors concluding that the cows tended to achieve a rather fixed amount of lying and prioritized the recuperation of rest over feeding time. This finding was again supported in more recent work with a $4-\mathrm{h}$ lying deprivation, with high-producing cows showing a greater propensity to rest rather than eat (Norring and Valros, 2016).

Other studies have extended the restriction of lying to longer periods of time to investigate other behavioral and physiological effects of inadequate rest. Cows kept in tiestalls deprived of lying for 2 periods of $7 \mathrm{~h} / \mathrm{d}$ for 3 wk showed lowered concentrations of circulating growth hormone (Munksgaard and Løvendahl, 1993), an increase in the frequency of transitions between behaviors, increased oral manipulation, and elevated baseline blood adrenocorticotropic hormone concentra- 
tions (Munksgaard and Simonsen, 1996). In a similar study on young bulls, behavioral changes indicative of physical strain and frustration were evident along with changes to the hypothalamo-pituitary adrenal axis (Munksgaard et al., 1999). In another study, $7 \mathrm{~d}$ of almost $16 \mathrm{~h}$ of lying restriction/d altered the hypothalamo-pituitary adrenal axis, but a similar duration of moderate $75 \%$ feed restriction did not (Fisher et al., 2002). This emphasizes the difficulty the cow has in compensating for loss of lying time compared with feeding time. A common adaptation to a reduction in feeding time or feed bunk competition is for cows to increase their rate of feeding (Munksgaard et al., 2005; Proudfoot et al., 2009). Unfortunately, cattle cannot increase the rate of lying once they are recumbent, and there is no similar adaptation for lost lying time.

Others have focused on the quality of rest rather than the hours of lying, with a particular focus on sleep. Early sleep studies used invasive brain-implanted electrodes that limited cow movement (Ruckebusch, 1972, 1974), but more recent work has used a noninvasive electroencephalogram with electrodes attached to the skin surface, which allow greater behavioral freedom and more accurate assessments (Ternman et al., 2012, 2019; Kull et al., 2019). Three categories of sleep have been defined from these studies: (1) rapid eye movement sleep, where the cow is recumbent, unable to lift her head or ruminate, and often lying in the closed position with the head turned back against the flank; (2) non-rapid eye movement sleep, where the cow is lying with the head lifted but immobile; and (3) drowsing, which appears to be an intermediate state between non-rapid eye movement sleep and being awake. Although total sleep time accounts for only 3 to $4 \mathrm{~h} / \mathrm{d}$ of the cow's total time budget, sleep deprivation is a significant component of lying deprivation, which may have an additive and detrimental effect on health and productivity (Kull et al., 2019).

The aforementioned studies demonstrate that cow comfort is adversely affected by lying deprivation in housed cattle, and significant behavioral and physiological changes occur when cows fail to achieve adequate rest that may affect longevity. However, there is a lack of consensus on what constitutes adequate rest for confinement-housed adult dairy cows.

A dairy cow's time budget is dominated by time spent eating and resting across a variety of housing and management systems. For pasture cattle, time spent grazing is usually around 8 to $9 \mathrm{~h} / \mathrm{d}$ and lying times typically average 7 to $11 \mathrm{~h} / \mathrm{d}$ (Rind and Phillips, 1999; Phillips and Rind, 2001; Tucker et al., 2007; Beggs et al., 2018). When cows are confinement housed and fed a TMR, eating time is compressed to around 3 to 5 h/d (Gomez and Cook, 2010; DeVries, 2019), leaving a surplus of 3 to $5 \mathrm{~h}$ of time compared with grazing, during which the cow is free to perform other important activities, including rest, socialization, exercise, and drinking, once milking time is accounted for. Given that the cows are usually on a hard concrete surface rather than dirt when standing in freestall housing, it would be expected that at least some of the surplus time would be directed toward rest. Studies in lactating dairy cows in confinement-housed freestall facilities with 10 or more surveyed herds report resting behavior with a range of herd mean lying times from 10.3 to 12.0 $\mathrm{h} / \mathrm{d}$, with cows achieving this rest taking a mean of 10 lying bouts per day, each with a mean duration of 1.2 $\mathrm{h}$ (Table 1). This range in lying time is slightly greater but perhaps, surprisingly, not drastically different from that seen in grazing herds. It is common to see large variations in intra- and interherd lying times (Ito et al., 2009; Bewley et al., 2010), with times ranging from 4 to $18 \mathrm{~h} / \mathrm{d}$ between individual cows; this is reflective of the effects of cow-related and housing- and managementrelated factors that may positively and negatively affect resting behavior. Thus, to more fully comprehend the influence of cow comfort on longevity and define what constitutes optimal rest for housed dairy cattle, it is important to consider the effect of these factors.

\section{COW-RELATED FACTORS INFLUENCING RESTING BEHAVIOR}

Cow-related factors that may influence lying times include parity, stage of the lactation cycle, milk yield, ill health, lameness, and individual cow preferences that are difficult to evaluate. There is a general consensus that multiparous nonlactating dairy cattle in freestall housing systems generally lie for around 12 to $13 \mathrm{~h} / \mathrm{d}$ at 2 to $3 \mathrm{wk}$ before calving, which decreases to a nadir at calving time of 10 to $10.5 \mathrm{~h} / \mathrm{d}$ (Huzzey et al., 2005; Proudfoot et al., 2010; Calderon and Cook, 2011; Lobeck-Luchterhand et al., 2015; Borchers et al., 2017). This change is brought about by an increase in the number of lying bouts coupled with a decrease in their duration. Nulliparous cows follow a similar pattern but have somewhat shorter resting times and shorter lying bouts (Kaufman et al., 2016; Borchers et al., 2017).

Several studies have identified differences in lying behavior by parity and stage of lactation. Primiparous cows appear to begin lactation by taking a greater number of shorter lying bouts. As lactation progresses, they shift toward the resting behavior typical of multiparous cows, which is characterized by fewer longer lying bouts (Vasseur et al., 2012; Solano et al., 2016). In some but not all studies, this difference in resting behavior can lead to an observed increase in lying time with increasing DIM (Bewley et al., 2010; Gomez and Cook, 2010; 
Table 1. A selection of published surveys of mean herd lying times with samples of 10 or more herds (total $=453$ farms)

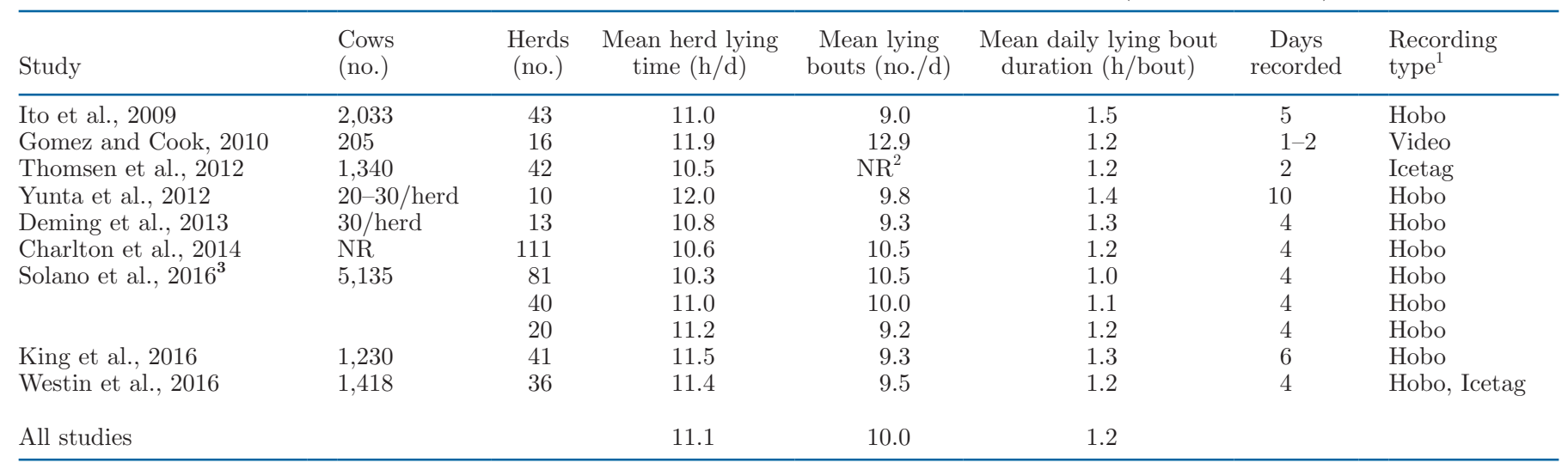

${ }^{1}$ Hobo (Hobo Pendant G Acceleration, Onset Computer Corp., Pocasset, MA); Icetag (IceRobotics, Edinburgh, UK).

${ }^{2}$ Not recorded.

${ }^{3}$ Study was divided into 3 provinces: Alberta ( 81 herds), Ontario (40 herds), and Quebec (20 herds).

Ito et al., 2014; Westin et al., 2016; Morabito et al., 2017).

Confusion exists regarding the relationship between milk yield and lying behavior. A positive association is supported by the negative effect of lying deprivation on lactogenic hormones such as growth hormone (Munksgaard and Løvendahl, 1993) and studies that show an increase in blood flow to the udder when lactating cows are lying (Metcalf et al., 1992), with a belief that this is associated with a significant increase in the delivery of nutrients to the udder. Contrary to this, a plethora of studies show that lying time is negatively associated with milk yield at the individual-cow level (Bewley et al., 2010; DeVries et al., 2011; Norring et al., 2012; Vasseur et al., 2012; Solano et al., 2016). It is more likely that high-producing dairy cows, who must spend more time eating and who may spend more time milking, have less available time for rest. That is not to say that higher lying times are not beneficial for improved milk production at the herd level, as was the case in a recent survey of 100 tiestall herds (Villettaz Robichaud et al., 2019a), although it is notable that the same group failed to find such an association in freestall herds that were similarly evaluated (Villettaz Robichaud et al., 2019b).

Ill health, particularly during the early postpartum period, alters resting behavior, but the literature reports somewhat inconsistent findings. Itle et al. (2015) showed that cows that went on to develop ketosis in early lactation compared with healthy cows had shorter lying time and prolonged bouts of standing during the week before calving but no difference in lying after calving. Kaufman et al. (2016), however, failed to show a change before calving but instead determined that sick ketotic multiparous cows spent more than $1.5 \mathrm{~h} / \mathrm{d}$ longer lying than healthy cows during the postpartum period. Similarly, increases in lying time and lying bout duration have also been associated with other health events, including displaced abomasum, metritis, and pneumonia (King et al., 2017a).

The effect of lameness on the resting behavior of dairy cattle is complex and deserves attention separate from other causes of ill health, as the effect likely depends on the severity of lameness, the pain associated with it, and interactions with housing factors such as the resting surface and the time available for rest. Some studies have demonstrated a reduction in lying time in moderate to severely lame cows (Chaplin et al., 2000; Cook et al., 2004; Gomez and Cook, 2010); others have found no effect on lying time (Yunta et al., 2012; King et al., 2017b), whereas most studies report an increase in lying time (Ito et al., 2010; Blackie et al., 2011; Calderon and Cook, 2011; Thomsen et al., 2012; Sepúlveda-Varas et al., 2014; Solano et al., 2016; Westin et al., 2016; Morabito et al., 2017; Weigele et al., 2018). A hypothesis to explain this variability suggests that the change in behavior is related to pain and discomfort as the cow rises and lies down; thus, the effect of lameness can be bidirectional. Cows may struggle to stand and lie down for prolonged periods or struggle to lie down and stand for prolonged periods of time before they are able to lie back down (Cook and Nordlund, 2009; Gomez and Cook, 2010). This is supported by a consistent increase in standing time in the stall observed in lame cows housed on mattress freestalls rather than deep-bedded stalls (Cook et al., 2004, 2008; Gomez and Cook, 2010), which goes unreported in studies using lying data loggers that fail to track standing location. Also, the tendency for the increase in lying time observed in some studies to be associated with longer 
lying bout duration (Ito et al., 2010; Thomsen et al., 2012; Yunta et al., 2012; Sepúlveda-Varas et al., 2014; Solano et al., 2016), greater variation in bout duration (Ito et al., 2010; Solano et al., 2016), and a reduction in the number of bouts taken per day (Gomez and Cook, 2010; Solano et al., 2016) is supportive of a stance that lame cows struggle to transition between standing and lying positions. These changes skew toward cows having both abnormally short and abnormally long lying times (Cook, 2019).

Given the high rates of lameness observed in confinement-housed dairy herds (von Keyserlingk et al., 2012; Cook et al., 2016), the fact that older multiparous cows have a greater propensity to be lame than primiparous cows in these herds (Espejo et al., 2006), that lameness increases the risk for other illness, particularly during the early postpartum period (Vergara et al., 2014; Neves et al., 2017), and that barn design can affect lying time (Solano et al., 2016), it is understandable that it is challenging to arrive at consistent conclusions across studies regarding the association between ill health and lameness and resting behavior, with so many interactions. However, these studies make the case that long lying times can be associated with older cows, late lactation, ill health, and lameness and are not associated with high milk production. Thus, improved cow comfort is not always reflected by cows being able to lie down for longer periods; rather, it is more likely that comfort is associated with the ability of the cow to lie down when, and for the amount of time, she desires. This ability would represent optimized resting behavior.

\section{HOUSING AND MANAGEMENT FACTORS INFLUENCING RESTING BEHAVIOR}

The housing- and management-related factors that have the potential to optimize rest of housed dairy cattle include design of the resting space and surface, the ability for the cow to access a place to rest driven by stocking density, the time spent in the pen, and the thermal microenvironment of the resting space.

Numerous studies have demonstrated that aspects of the design of the resting space can affect lying times. Longer lying times have been observed in freestalls that are wider and more appropriately sized to the size of the cow using them (Tucker et al., 2004; Solano et al., 2016; Morabito et al., 2017) without elements that restrict normal rising movement and comfortable lying positions (Tucker et al., 2006). However, one of the most significant factors influencing lying behavior is the type of resting surface. Cows appear particularly sensitive to the DM of the bedding. Significantly reduced lying times were observed when cows were provided bedding with $27 \%$ compared with $86 \%$ DM (Fregonesi et al., 2007b), which has relevance to the growing use of high-moisture recycled-manure solid bedding for dairy cattle. Dry, deep loose-bedded stalls rather than stalls with mat or mattress products improve lying times (Tucker and Weary, 2004; Gomez and Cook, 2010; Ito et al., 2010, 2014; Solano et al., 2016) and are often associated with fewer and longer lying bouts (Cook et al., 2008; Gomez and Cook, 2010; van Gastelen et al., 2011; Ito et al., 2014; King et al., 2016). Deep loose bedding, and deep-bedded sand stalls in particular, likely demonstrate their greatest benefit through an interaction with lameness, as described previously, by facilitating rising and lying movements through the provision of cushion, traction, and support (Cook and Nordlund, 2009; Ito et al., 2010), effectively normalizing resting behavior. Indeed, this may be the reason why lame cows bedded on sand rather than straw had improved hoof lesion recovery rates despite mean lying times being shorter (Norring et al., 2008) and why water beds, which provide little cushion and traction to the foot while the cow is rising and lying down, appear to have the shortest reported lying times (Solano et al., 2016) and are associated with very high rates of severe lameness (Salfer et al., 2018).

Deprivation studies have suggested that access to a resting space is important to the cow, and in freestall facilities, stocking rates that exceed more than 1 cow per stall $(100 \%)$ have a negative effect on lying time (Fregonesi et al., 2007a; Krawczel et al., 2012; Krawczel and Lee, 2019). Time out of the freestall pen milking can also negatively affect the time available for rest (Gomez and Cook, 2010). It is recommended that the facility be designed so that time spent milking each day should not exceed $3 \mathrm{~h}$ total (Cook, 2019) to optimize the time available for rest and reduce the risk for lameness (Jewell et al., 2019). Indeed, Charlton et al. (2014) showed that no farm achieved more than 12 $\mathrm{h}$ of lying time/d when stocking rates exceeded $100 \%$ or when time milking exceeded $3.7 \mathrm{~h} / \mathrm{d}$. High stocking rates were associated with an increased number of lying bouts and a decrease in their duration, consistent with competition for a resting place and an increase in displacements from the stall (Fregonesi et al., 2007a).

Resting behavior appears to be particularly sensitive to the thermal microenvironment, with changes in behavior and a reduction in lying time observed at around a temperature-humidity index of 68 within the pen (Cook et al., 2007). The effect on lying time can be profound with short-term increases in heat load, with a loss of more than $3 \mathrm{~h}$ of lying time/d (Cook et al., 2007; Nordlund et al., 2019). This reduction is associated with a decrease in the duration of the lying bout but no change in the number of daily bouts (King et al., 2017a; Nordlund et al., 2019). In summary, opti- 
mal resting behavior is favored in facilities with welldesigned resting areas with deep bedding, particularly sand, at stocking rates at or below $100 \%$, when cows are allowed sufficient time in the pen to access the resting area, under conditions designed to reduce heat stress with the use of fans to assist air movement and water-cooling strategies.

\section{EFFECT OF ABNORMAL RESTING BEHAVIOR ON HEALTH AND LONGEVITY}

The determination of when an individual cow leaves the herd is a complex economic and biological equation solved in a wide variety of ways by dairy producers, and it has been a challenge to demonstrate a clear link between comfort and longevity. Brotzman et al. (2015a) performed a cluster analysis using multiple DHIA variables to identify 6 groupings of dairy herds with different management approaches and outcomes. The lowest mean turnover rate (33\%) was observed in 2 separate clusters of herds with the highest and the lowest milk production of all of the groups. By contrast, the highest turnover rate (43\%) was observed in a single cluster of larger herds with high milk production and excellent reproductive performance, suggesting that this high rate was being supported by replacement supply. Thus, longevity without the maintenance of health does not necessarily lead to improved herd performance. Poor culling management can retain older, lower producing cows in the herd with poor udder health and high rates of lameness, whereas high culling rates can shift the herd demographic toward a greater number of younger, healthier animals. At some point, economics are the main determinant of the optimal rate of culling in any given herd (De Vries, 2017). Overall well-being and the influence of cow comfort are perhaps better reflected by the quality of the animals leaving the herd rather than the absolute number.

A report on 76,886 dairy cattle slaughtered in 13 countries revealed that the most common conditions observed were severe lameness, low body condition, and poor udder condition (Vogel et al., 2018). Similarly, studies of marketed cattle in North America repeatedly confirm that lameness is the most commonly identified condition affecting culled dairy cattle (Ahola et al., 2011; Dahl-Pedersen et al., 2018; Moorman et al., 2018), and it is in the prevention and management of lameness that cow comfort likely influences herd survival most significantly.

Over the last 2 decades, our understanding of the pathogenesis of claw horn disruption has evolved from believing it is a feeding-related problem due to ruminal acidosis (Nocek, 1997) to believing it is a problem caused by contusion of the corium beneath the third phalanx due to a failure of the suspensory apparatus triggered around calving time (Tarlton et al., 2002; Knott et al., 2007) to an in-depth investigation of the role of the digital fat pad and body condition (Bicalho and Oikonomou, 2013; Randall et al., 2015). Throughout this time, the important role of cow comfort was ever-present as a factor that potentially magnified the effects of these complex pathways (Cook and Nordlund, 2009; Randall et al., 2018b).

Surprisingly, however, in contrast to the many studies of behavior once the cow has become lame, very few have been able to document the role of comfort, and lying time in particular, in the creation of new cases of lameness. To do so is a particular challenge because it is difficult to control for the influence of cows that are already lame or at risk of becoming lame again. We now know that the risk for hoof lesion development is very high in cows that have suffered a prior lesion event (Oikonomou et al., 2013; Randall et al., 2018a), and permanent inflammatory changes to the third phalanx likely are the root cause of this susceptibility (Newsome et al., 2016). Two studies stand out as pivotal in support of the effect of lying time on new lameness events. Proudfoot et al. (2010) were able to show that cows whose hooves were evaluated before calving and up to $15 \mathrm{wk}$ of lactation that developed a claw horn lesion in mid lactation had shorter resting times and stood more before calving and immediately afterward compared with healthy cows. Similarly, Sepúlveda-Varas et al. (2018) monitored lying time in pastured primiparous cows and found that those that developed a claw lesion by mid lactation had decreased lying time $(1.2 \mathrm{~h} / \mathrm{d}$ less) wk 3 after calving compared with healthy cows. When coupled with observations in herds that make improvements to the freestall area, where lying times improve and lameness rates decrease (Morabito et al., 2017), there exists the real possibility that abnormally short resting times may be the primary cause of the inflammatory changes at the corium, causing the horn disruption and bony changes observed. Standing activity has been proposed as a significant primary factor in the development of plantar fasciitis in humans (Riddle et al., 2003), making the possibility intriguing that cow comfort is a primary driver of claw horn disruption rather than merely a secondary contributing factor.

In the freestall-housed herd clusters with a combination of high milk production and low culling rate, Brotzman et al. (2015b) noted that high levels of performance were associated with excellent management of the transition period, good fertility, and high standards of udder health. When surveyed, 68 to $71 \%$ of these herds used deep, loose stall bedding and achieved 
very low rates of lameness and injury (Brotzman et al., 2015b; Cook et al., 2016). Similarly, Rowbotham and Ruegg (2015) found higher rates of milk production and improved udder health in sand-bedded freestall herds compared with herds using manure solids and other types of organic bedding over a mattress, a finding repeated in Danish freestall herds (Andreasen and Forkman, 2012). In both tiestall and freestall facilities, comfort indicators were associated with improved longevity in a Canadian survey: a lower proportion of cows in third or greater parity was associated with greater between-cow variability in lying time in tiestall herds (Villettaz Robichaud et al., 2019a), whereas in freestall herds, longer stall bed platforms were associated with the presence of a greater proportion of older cows, and culling rate was less in herds with a lower prevalence of lameness (Villettaz Robichaud et al., 2019b). Common to studies of high-performing dairy herds with lower rates of herd turnover is the control of lameness. As discussed, lame cows show different patterns of resting behavior, spend less time feeding (Gomez and Cook, 2010; Norring et al., 2014; Grimm et al., 2019), suffer poor reproductive performance (reviewed by Huxley, 2013), are at increased risk for other postpartum diseases (Vergara et al., 2014; Neves et al., 2017), and are culled at higher rates than healthy cows (Booth et al., 2004; Cramer et al., 2009), particularly when affected by noninfectious rather than infectious causes of lameness (Cramer et al., 2009).

Lameness control is a priority if we are to improve cow longevity in housed dairy herds. In this regard, cow comfort and the optimization of rest have a critical role to play. Short lying times have negative behavioral and physiological effects on the cow and are significant in claw horn lesion development. However, long lying times are not necessarily a reflection of good cow comfort and improved health. Rather, we must seek to optimize the resting behavior of the dairy cow. Recently, Piñeiro et al. (2019) showed that for every 1-h increase in lying time in the early postpartum period, the risk for culling by 60 DIM increased by 1 percentage point and cows with a lying time of 9 to $13 \mathrm{~h} / \mathrm{d}$ had a greater probability of pregnancy than cows lying more than 13 $\mathrm{h} / \mathrm{d}$. These findings support the view that optimized resting behavior allows cows to lie down when they choose to do so, for as long as they need to, rather than a view that longer lying times are always beneficial. Optimal resting behavior in freestall-housed cattle may be reflected by herd mean lying times in excess of those reported from surveys in Table 1 , with herd mean lying times of 11.5 to $12.5 \mathrm{~h} / \mathrm{d}$ possible under optimal circumstances (Cook et al., 2004; Charlton et al., 2014; Solano et al., 2016).

\section{CONCLUSIONS}

Although there exists a general acceptance that enhanced cow comfort improves cow longevity in confinement freestall-housed dairy herds, the association has received scant research attention. Because lameness and poor body condition are commonly found among the cull cow population, it seems likely that the major influence is through the onset and management of lameness. Cow comfort, and resting behavior in particular, has a central role to play in reducing the risk for claw lesion development and reducing the negative effects of lameness on the cow once she becomes lame by giving cows the ability to lie down when, and for the amount of time, they desire. Optimized resting behavior is favored in facilities with well-designed resting areas with deep bedding, particularly sand, where each cow may access a place to rest and be provided sufficient time in the pen to access the resting area, combined with measures to reduce the negative effects of heat stress.

\section{ACKNOWLEDGMENTS}

The authors have not stated any conflicts of interest.

\section{REFERENCES}

Ahola, J. K., H. A. Foster, D. L. Vanoverbeke, K. S. Jensen, R. L. Wilson, J. B. Glaze Jr., T. E. Fife, C. W. Gray, S. A. Nash, R. R. Panting, and N. R. Rimbey. 2011. Survey of quality defects in market beef and dairy cows and bulls sold through livestock auction markets in the Western United States: I. Incidence rates. J. Anim. Sci. 89:1474-1483. https://doi.org/10.2527/jas.2010-3170.

Andreasen, S. N., and B. Forkman. 2012. The welfare of dairy cows is improved in relation to cleanliness and integument alterations on the hocks and lameness when sand is used as stall surface. J. Dairy Sci. 95:4961-4967. https://doi.org/10.3168/jds.2011-5169.

Beggs, D. S., E. C. Jongman, P. E. Hemsworth, and A. D. Fisher. 2018. Implications of prolonged milking time on time budgets and lying behavior of cows in large pasture-based dairy herds. J. Dairy Sci. 101:10391-10397. https://doi.org/10.3168/jds.2018-15049.

Bewley, J. M., R. E. Boyce, J. Hockin, L. Munksgaard, S. D. Eicher, M. E. Einstein, and M. M. Schutz. 2010. Influence of milk yield, stage of lactation, and body condition on dairy cattle lying behaviour measured using an automated activity monitoring sensor. J. Dairy Res. 77:1-6. https://doi.org/10.1017/S0022029909990227.

Bicalho, R. C., and G. Oikonomou. 2013. Control and prevention of lameness associated with claw lesions in dairy cows. Livest. Sci. 156:96-105. https://doi.org/10.1016/j.livsci.2013.06.007.

Blackie, N., E. Bleach, J. Amory, and J. Scaife. 2011. Impact of lameness on gait characteristics and lying behaviour of zero grazed dairy cattle in early lactation. Appl. Anim. Behav. Sci. 129:67-73. https://doi.org/10.1016/j.applanim.2010.10.006.

Booth, C. J., L. D. Warnick, Y. T. Gröhn, D. O. Maizon, C. L. Guard, and D. Janssen. 2004. Effect of lameness on culling in dairy cows. J. Dairy Sci. 87:4115-4122. https://doi.org/10.3168/jds.S0022 -0302(04)73554-7.

Borchers, M. R., Y. M. Chang, K. L. Proudfoot, B. A. Wadsworth, A. E. Stone, and J. M. Bewley. 2017. Machine-learning-based calving prediction from activity, lying, and ruminating behaviors in dairy cattle. J. Dairy Sci. 100:5664-5674. https://doi.org/10.3168/jds .2016-11526. 
Brotzman, R. L., N. B. Cook, K. Nordlund, T. B. Bennett, A. Gomez Rivas, and D. Döpfer. 2015a. Cluster analysis of Dairy Herd Improvement data to discover trends in performance characteristics in large Upper Midwest dairy herds. J. Dairy Sci. 98:3059-3070. https://doi.org/10.3168/jds.2014-8369.

Brotzman, R. L., D. Döpfer, M. R. Foy, J. P. Hess, K. V. Nordlund, T. B. Bennett, and N. B. Cook. 2015b. Survey of facility and management characteristics of large, Upper Midwest dairy herds clustered by Dairy Herd Improvement records. J. Dairy Sci. 98:8245-8261. https://doi.org/10.3168/jds.2014-9264.

Calderon, D. F., and N. B. Cook. 2011. The effect of lameness on the resting behavior and metabolic status of dairy cattle during the transition period in a freestall-housed dairy herd. J. Dairy Sci. 94:2883-2894. https://doi.org/10.3168/jds.2010-3855.

Chaplin, S. J., H. E. Ternent, J. E. Offer, D. N. Logue, and C. H. Knight. 2000. A comparison of hoof lesions and behaviour in pregnant and early lactation heifers at housing. Vet. J. 159:147-153. https://doi.org/10.1053/tvjl.1999.0404.

Charlton, G. L., D. B. Haley, J. Rushen, and A. M. de Passillé. 2014. Stocking density, milking duration, and lying times of lactating cows on Canadian freestall dairy farms. J. Dairy Sci. 97:26942700. https://doi.org/10.3168/jds.2013-6923.

Cook, N. B. 2019. Designing facilities for the adult dairy cow during the nonlactation and early lactation period. Vet. Clin. North Am. Food Anim. Pract. 35:125-138. https://doi.org/10.1016/j.cvfa 2018.10.008

Cook, N. B., T. B. Bennett, and K. V. Nordlund. 2004. Effect of free stall surface on daily activity patterns in dairy cows with relevance to lameness prevalence. J. Dairy Sci. 87:2912-2922. https://doi .org/10.3168/jds.S0022-0302(04)73422-0.

Cook, N. B., J. P. Hess, M. R. Foy, T. B. Bennett, and R. L. Brotzman. 2016. Management characteristics, lameness, and body injuries of dairy cattle housed in high-performance dairy herds in Wisconsin. J. Dairy Sci. 99:5879-5891. https://doi.org/10.3168/jds.2016 $-10956$.

Cook, N. B., M. J. Marin, R. L. Mentink, T. B. Bennett, and M. J. Schaefer. 2008. Comfort zone-design free stalls: Do they influence the stall use behavior of lame cows? J. Dairy Sci. 91:4673-4678. https://doi.org/10.3168/jds.2007-0910.

Cook, N. B., R. L. Mentink, T. B. Bennett, and K. Burgi. 2007. The effect of heat stress and lameness on time budgets of lactating dairy cows. J. Dairy Sci. 90:1674-1682. https://doi.org/10.3168/ jds.2006-634.

Cook, N. B., and K. V. Nordlund. 2009. The influence of the environment on dairy cow behavior, claw health and herd lameness dynamics. Vet. J. 179:360-369. https://doi.org/10.1016/j.tvjl.2007 .09 .016 .

Cooper, M. D., D. R. Arney, and C. J. C. Phillips. 2007. Two- or fourhour lying deprivation on the behavior of lactating dairy cows. J. Dairy Sci. 90:1149-1158. https://doi.org/10.3168/jds.S0022 -0302(07)71601-6.

Cramer, G., K. D. Lissemore, C. L. Guard, K. E. Leslie, and D. F. Kelton. 2009. The association between foot lesions and culling risk in Ontario Holstein cows. J. Dairy Sci. 92:2572-2579. https://doi .org/10.3168/jds.2008-1532.

Dahl-Pedersen, K., M. S. Herskin, H. Houe, and P. T. Thomsen. 2018 A descriptive study of the clinical condition of cull dairy cows before transport to slaughter. Livest. Sci. 218:108-113. https://doi .org/10.1016/j.livsci.2018.11.001.

Deming, J. A., R. Bergeron, K. E. Leslie, and T. J. DeVries. 2013. Associations of housing, management, milking activity and standing and lying behavior of dairy cows milked in automated systems. J. Dairy Sci. 96:344-351.

De Vries, A. 2017. Economic trade-offs between genetic improvement and longevity in dairy cattle. J. Dairy Sci. 100:4184-4192. https:/ /doi.org/10.3168/jds.2016-11847.

DeVries, T. J. 2019. Feeding behavior, feed space, and bunk design and management for adult dairy cattle. Vet. Clin. North Am. Food Anim. Pract. 35:61-76. https://doi.org/10.1016/j.cvfa.2018 .10 .003 .
DeVries, T. J., J. A. Deming, J. Rodenburg, G. Seguin, K. E. Leslie, and H. W. Barkema. 2011. Association of standing and lying behavior patterns and incidence of intramammary infection in dairy cows milked with an automatic milking system. J. Dairy Sci 94:3845-3855. https://doi.org/10.3168/jds.2010-4032.

Espejo, L. A., M. I. Endres, and J. A. Salfer. 2006. Prevalence of lameness in high-producing Holstein cows housed in freestall barns in Minnesota. J. Dairy Sci. 89:3052-3058. https://doi.org/10.3168/ jds.S0022-0302(06)72579-6.

Fisher, A. D., G. A. Verkerk, C. J. Morrow, and L. R. Matthews. 2002. The effects of feed restriction and lying deprivation on pituitaryadrenal axis regulation in lactating cows. Livest. Prod. Sci. 73:255263. https://doi.org/10.1016/S0301-6226(01)00246-9.

Fregonesi, J. A., C. B. Tucker, and D. M. Weary. 2007a. Overstocking reduces lying time in dairy cows. J. Dairy Sci. 90:3349-3354. https: //doi.org/10.3168/jds.2006-794.

Fregonesi, J. A., D. M. Veira, M. A. G. Von Keyserlingk, and D. M. Weary. 2007b. Effects of bedding quality on lying behavior of dairy cows. J. Dairy Sci. 90:5468-5472. https://doi.org/10.3168/jds.2007 $-0494$.

Gomez, A., and N. B. Cook. 2010. Time budgets of lactating dairy cattle in commercial freestall herds. J. Dairy Sci. 93:5772-5781. https://doi.org/10.3168/jds.2010-3436.

Grimm, K., B. Haidn, M. Erhard, M. Tremblay, and D. Döpfer. 2019 New insights into the association between lameness, behavior, and performance in Simmental cows. J. Dairy Sci. 102:2453-2468. https://doi.org/10.3168/jds.2018-15035.

Huxley, J. N. 2013. Impact of lameness and claw lesions in cows on health and production. Livest. Sci. 156:64-70. https://doi.org/10 .1016/j.livsci.2013.06.012.

Huzzey, J. M., M. A. G. von Keyserlingk, and D. M. Weary. 2005. Changes in feeding, drinking, and standing behavior of dairy cows during the transition period. J. Dairy Sci. 88:2454-2461. https:// doi.org/10.3168/jds.S0022-0302(05)72923-4.

Itle, A. J., J. M. Huzzey, D. M. Weary, and M. A. G. von Keyserlingk. 2015. Clinical ketosis and standing behavior in transition cows. J. Dairy Sci. 98:128-134. https://doi.org/10.3168/jds.2014-7932.

Ito, K., N. Chapinal, D. M. Weary, and M. A. G. von Keyserlingk. 2014. Associations between herd-level factors and lying behavior of freestall-housed dairy cows. J. Dairy Sci. 97:2081-2089. https:/ /doi.org/10.3168/jds.2013-6861.

Ito, K., M. A. G. von Keyserlingk, S. J. LeBlanc, and D. M. Weary. 2010. Lying behavior as an indicator of lameness in dairy cows. J. Dairy Sci. 93:3553-3560. https://doi.org/10.3168/jds.2009-2951.

Ito, K., D. M. Weary, and M. A. G. von Keyserlingk. 2009. Lying behavior: Assessing within- and between-herd variation in free-stallhoused dairy cows. J. Dairy Sci. 92:4412-4420. https://doi.org/10 $.3168 /$ jds.2009-2235.

Jensen, M. B., L. J. Pedersen, and L. Munksgaard. 2005. The effect of reward duration on demand functions for rest in dairy heifers and lying requirements as measured by demand functions. Appl. Anim. Behav. Sci. 90:207-217. https://doi.org/10.1016/j.applanim .2004.08.006.

Jewell, M. T., M. Cameron, J. Spears, S. L. McKenna, M. S. Cockram, J. Sanchez, and G. P. Keefe. 2019. Prevalence of lameness and associated risk factors on dairy farms in the Maritime Provinces of Canada. J. Dairy Sci. 102:3392-3405. https://doi.org/10.3168/jds .2018-15349.

Kaufman, E. I., S. J. LeBlanc, B. W. McBride, T. F. Duffield, and T. J. DeVries. 2016. Short communication: Association of lying behavior and subclinical ketosis in transition dairy cows. J. Dairy Sci. 99:7473-7480. https://doi.org/10.3168/jds.2016-11185.

King, M. T. M., K. M. Dancy, S. J. LeBlanc, E. A. Pajor, and T. J. DeVries. 2017a. Deviations in behavior and productivity data before diagnosis of health disorders in cows milked with an automated system. J. Dairy Sci. 100:8358-8371. https://doi.org/10 .3168/jds.2017-12723.

King, M. T. M., S. J. LeBlanc, E. A. Pajor, and T. J. DeVries. 2017b. Cow-level associations of lameness, behavior, and milk yield of cows milked in automated systems. J. Dairy Sci. 100:4818-4828. https://doi.org/10.3168/jds.2016-12281. 
King, M. T. M., E. A. Pajor, S. J. LeBlanc, and T. J. DeVries. 2016. Associations of herd-level housing, management, and lameness prevalence with productivity and cow behavior in herds with automated milking systems. J. Dairy Sci. 99:9069-9079. https://doi .org/10.3168/jds.2016-11329.

Knott, L., J. F. Tarlton, H. Craft, and A. J. F. Webster. 2007. Effects of housing, parturition and diet change on the biochemistry and biomechanics of the support structures of the hoof of dairy heifers. Vet. J. 174:277-287. https://doi.org/10.1016/j.tvjl.2006.09.007.

Krawczel, P. D., L. B. Klaiber, R. E. Butzler, L. M. Klaiber, H. M. Dann, C. S. Mooney, and R. J. Grant. 2012. Short-term increases in stocking density affect the lying and social behavior, but not the productivity, of lactating Holstein dairy cows. J. Dairy Sci. 95:4298-4308. https://doi.org/10.3168/jds.2011-4687.

Krawczel, P. D., and A. R. Lee. 2019. Lying time and its importance to the dairy cow: Impact of stocking density and time budget stresses. Vet. Clin. North Am. Food Anim. Pract. 35:47-60. https: //doi.org/10.1016/j.cvfa.2018.11.002.

Kull, J. A., K. L. Proudfoot, G. M. Pighetti, J. M. Bewley, B. F. O'Hara, K. D. Donohue, and P. D. Krawczel. 2019. Effects of acute lying and sleep deprivation on the behavior of lactating dairy cows. PLoS One 14:e0212823. https://doi.org/10.1371/journal.pone 0212823

Ledgerwood, D. N., C. Winckler, and C. B. Tucker. 2010. Evaluation of data loggers, sampling intervals, and editing techniques for measuring the lying behavior of dairy cattle. J. Dairy Sci. 93:51295139. https://doi.org/10.3168/jds.2009-2945.

Lobeck-Luchterhand, K. M., P. R. B. Silva, R. C. Chebel, and M. I. Endres. 2015. Effect of stocking density on social, feeding, and lying behavior of prepartum dairy animals. J. Dairy Sci. 98:240-249. https://doi.org/10.3168/jds.2014-8492.

Metcalf, J. A., S. J. Roberts, and J. D. Sutton. 1992. Variations in blood flow to and from the bovine mammary gland measured using transit time ultrasound and dye dilution. Res. Vet. Sci. 53:59-63. https://doi.org/10.1016/0034-5288(92)90085-g.

Metz, J. H. M. 1985. The reaction of cows to a short-term deprivation of lying. Appl. Anim. Behav. Sci. 13:301-307. https://doi.org/10 $.1016 / 0168-1591(85) 90010-3$

Moorman, A. K. G., T. F. Duffield, M. A. Godkin, D. F. Kelton, J. Rau, and D. B. Haley. 2018. Associations between the general condition of culled dairy cows and selling price at Ontario auction markets. J. Dairy Sci. 101:10580-10588. https://doi.org/10.3168/ jds.2018-14519.

Morabito, E., H. W. Barkema, E. A. Pajor, L. Solano, D. Pellerin, and K. Orsel. 2017. Effects of changing freestall area on lameness, lying time, and leg injuries on dairy farms in Alberta, Canada. J. Dairy Sci. 100:6516-6526. https://doi.org/10.3168/jds.2016-12467.

Munksgaard, L., K. L. Ingvartsen, L. J. Pedersen, and V. K. M. Nielsen. 1999. Deprivation of lying down affects behaviour and pituitaryadrenal axis responses in young bulls. Acta Agric. Scand. A Anim. Sci. 49:172-178. https://doi.org/10.1080/090647099424088.

Munksgaard, L., M. B. Jensen, L. J. Pedersen, S. W. Hansen, and L. Matthews. 2005. Quantifying behavioural priorities - Effects of time constraints on behaviour of dairy cows, Bos taurus. Appl. Anim. Behav. Sci. 92:3-14. https://doi.org/10.1016/j.applanim .2004.11.005.

Munksgaard, L., and P. Løvendahl. 1993. Effects of social and physical stressors on growth hormone levels in dairy cows. Can. J. Anim. Sci. 73:847-853. https://doi.org/10.4141/cjas93-087.

Munksgaard, L., and H. B. Simonsen. 1996. Behavioral and pituitary adrenal-axis responses of dairy cows to social isolation and deprivation of lying down. J. Anim. Sci. 74:769-778. https://doi.org/10 $.2527 / 1996.744769 x$.

Neves, R. C., B. M. Leno, T. Stokol, T. R. Overton, and J. A. A. McArt. 2017. Risk factors associated with postpartum subclinical hypocalcemia in dairy cows. J. Dairy Sci. 100:3796-3804. https:// doi.org/10.3168/jds.2016-11970.

Newsome, R., M. J. Green, N. J. Bell, M. G. G. Chagunda, C. S. Mason, C. S. Rutland, C. J. Sturrock, H. R. Whay, and J. N. Huxley. 2016. Linking bone development on the caudal aspect of the dis- tal phalanx with lameness during life. J. Dairy Sci. 99:4512-4525. https://doi.org/10.3168/jds.2015-10202.

Nocek, J. E. 1997. Bovine acidosis: Implications on laminitis. J. Dairy Sci. 80:1005-1028. https://doi.org/10.3168/jds.S0022 -0302(97)76026-0.

Nordlund, K. V., P. Strassburg, T. Bennett, G. Oetzel, and N. Cook. 2019. Thermodynamics of standing and lying behavior in lactating dairy cows in freestall and parlor holding pens during conditions of heat stress. J. Dairy Sci. 102:6495-6507. https://doi.org/10.3168/ jds.2018-15891.

Norring, M., J. Häggman, H. Simojoki, P. Tamminen, C. Winckler, and M. Pastell. 2014. Short communication: Lameness impairs feeding behavior of dairy cows. J. Dairy Sci. 97:4317-4321. https:/ /doi.org/10.3168/jds.2013-7512.

Norring, M., E. Manninen, A. M. De Passillé, J. Rushen, L. Munksgaard, and H. Saloniemi. 2008. Effects of sand and straw bedding on the lying behavior, cleanliness, and hoof and hock injuries of dairy cows. J. Dairy Sci. 91:570-576. https://doi.org/10.3168/jds .2007-0452.

Norring, M., and A. Valros. 2016. The effect of lying motivation on cow behaviour. Appl. Anim. Behav. Sci. 176:1-5. https://doi.org/ 10.1016/j.applanim.2015.11.022.

Norring, M., A. Valros, and L. Munksgaard. 2012. Milk yield affects time budget of dairy cows in tie-stalls. J. Dairy Sci. 95:102-108. https://doi.org/10.3168/jds.2010-3458.

Oikonomou, G., N. B. Cook, and R. C. Bicalho. 2013. Sire predicted transmitting ability for conformation and yield traits and previous lactation incidence of foot lesions as risk factors for the incidence of foot lesions in Holstein cows. J. Dairy Sci. 96:3713-3722. https: //doi.org/10.3168/jds.2012-6308.

Phillips, C. J. C., and M. I. Rind. 2001. The effects on production and behavior of mixing uniparous and multiparous cows. J. Dairy Sci. 84:2424-2429. https://doi.org/10.3168/jds.S0022-0302(01)74692 -9 .

Piñeiro, J. M., B. T. Menichetti, A. A. Barragan, A. E. Relling, W. P. Weiss, S. Bas, and G. M. Schuenemann. 2019. Associations of postpartum lying time with culling, milk yield, cyclicity, and reproductive performance of lactating dairy cows. J. Dairy Sci. 102:3362-3375. https://doi.org/10.3168/jds.2018-15387.

Proudfoot, K. L., D. M. Veira, D. M. Weary, and M. A. G. von Keyserlingk. 2009. Competition at the feed bunk changes the feeding, standing, and social behavior of transition dairy cows. J. Dairy Sci. 92:3116-3123. https://doi.org/10.3168/jds.2008-1718.

Proudfoot, K. L., D. M. Weary, and M. A. G. von Keyserlingk. 2010. Behavior during transition differs for cows diagnosed with claw horn lesions in mid lactation. J. Dairy Sci. 93:3970-3978. https:// doi.org/10.3168/jds.2009-2767.

Randall, L. V., M. J. Green, M. G. G. Chagunda, C. Mason, S. C. Archer, L. E. Green, and J. N. Huxley. 2015. Low body condition predisposes cattle to lameness: An 8-year study of one dairy herd. J. Dairy Sci. 98:3766-3777. https://doi.org/10.3168/jds.2014-8863.

Randall, L. V., M. J. Green, L. E. Green, M. G. G. Chagunda, C. Mason, S. C. Archer, and J. N. Huxley. 2018a. The contribution of previous lameness events and body condition score to the occurrence of lameness in dairy herds: A study of 2 herds. J. Dairy Sci. 101:1311-1324. https://doi.org/10.3168/jds.2017-13439.

Randall, L. V., M. J. Green, and J. N. Huxley. 2018b. Use of statistical modelling to investigate the pathogenesis of claw horn disruption lesions in dairy cattle. Vet. J. 238:41-48. https://doi.org/10.1016/ j.tvjl.2018.07.002.

Riddle, D. L., M. Pulisic, P. Pidcoe, and R. E. Johnson. 2003. Risk factors for plantar fasciitis: A matched case-control study. J. Bone Joint Surg. Am. 85:872-877. https://doi.org/10.2106/00004623 -200305000-00015.

Rind, M. I., and C. J. C. Phillips. 1999. The effects of group size on the ingestive and social behaviour of grazing dairy cows. Anim. Sci. 68:589-596. https://doi.org/10.1017/S135772980005061X.

Rowbotham, R. F., and P. L. Ruegg. 2015. Association of bedding types with management practices and indicators of milk quality on larger Wisconsin dairy farms. J. Dairy Sci. 98:7865-7885. https:// doi.org/10.3168/jds.2015-9866. 
Ruckebusch, Y. 1972. The relevance of drowsiness in the circadian cycle of farm animals. Anim. Behav. 20:637-643. https://doi.org/ 10.1016/s0003-3472(72)80136-2.

Ruckebusch, Y. 1974. Sleep deprivation in cattle. Brain Res. 78:495499. https://doi.org/10.1016/0006-8993(74)90932-9.

Salfer, J. A., J. M. Siewert, and M. I. Endres. 2018. Housing, management characteristics, and factors associated with lameness, hock lesion, and hygiene of lactating dairy cattle on Upper Midwest United States dairy farms using automatic milking systems. J. Dairy Sci. 101:8586-8594. https://doi.org/10.3168/jds.2017-13925.

Sepúlveda-Varas, P., J. Lomb, M. A. G. von Keyserlingk, R. Held, H. Bustamante, and N. Tadich. 2018. Claw horn lesions in mid-lactation primiparous dairy cows under pasture-based systems: Association with behavioral and metabolic changes around calving. J Dairy Sci. 101:9439-9450. https://doi.org/10.3168/jds.2018-14674.

Sepúlveda-Varas, P., D. M. Weary, and M. A. G. von Keyserlingk. 2014. Lying behavior and postpartum health status in grazing dairy cows. J. Dairy Sci. 97:6334-6343. https://doi.org/10.3168/ jds.2014-8357.

Solano, L., H. W. Barkema, E. A. Pajor, S. Mason, S. J. LeBlanc, C. G. R. Nash, D. B. Haley, D. Pellerin, J. Rushen, A. M. de Passillé, E. Vasseur, and K. Orsel. 2016. Associations between lying behavior and lameness in Canadian Holstein-Friesian cows housed in freestall barns. J. Dairy Sci. 99:2086-2101. https://doi.org/10 3168/jds.2015-10336.

Tarlton, J. F., D. E. Holah, K. M. Evans, S. Jones, G. R. Pearson, and A. J. F. Webster. 2002. Biomechanical and histopathological changes in the support structures of bovine hooves around the time of first calving. Vet. J. 163:196-204. https://doi.org/10.1053/tvjl .2001.0651.

Ternman, E., L. Hänninen, M. Pastell, S. Agenäs, and P. P. Nielsen. 2012. Sleep in dairy cows recorded with a non-invasive EEG technique. Appl. Anim. Behav. Sci. 140:25-32. https://doi.org/10 .1016/j.applanim.2012.05.005.

Ternman, E., E. Nilsson, P. P. Nielsen, M. Pastell, L. Hänninen, and S. Agenäs. 2019. Rapid eye movement sleep time in dairy cows changes during the lactation cycle. J. Dairy Sci. 102:5458-5465. https://doi.org/10.3168/jds.2018-15950.

Thomsen, P. T., L. Munksgaard, and J. T. Sørensen. 2012. Locomotion scores and lying behaviour are indicators of hoof lesions in dairy cows. Vet. J. 193:644-647. https://doi.org/10.1016/j.tvjl .2012 .06 .046

Tucker, C. B., D. E. Dalley, J.-L. K. Burke, and D. A. Clark. 2007. Milking cows once daily influences behavior and udder firmness at peak and mid lactation. J. Dairy Sci. 90:1692-1703. https://doi .org/10.3168/jds.2006-577.

Tucker, C. B., and D. M. Weary. 2004. Bedding on geotextile mattresses: How much is needed to improve cow comfort? J. Dairy Sci. 87:2889-2895. https://doi.org/10.3168/jds.S0022-0302(04)73419 $-0$

Tucker, C. B., D. M. Weary, and D. Fraser. 2004. Free-stall dimensions: Effects on preference and stall usage. J. Dairy Sci. 87:12081216. https://doi.org/10.3168/jds.S0022-0302(04)73271-3.

Tucker, C. B., G. Zdanowicz, and D. M. Weary. 2006. Brisket boards reduce freestall use. J. Dairy Sci. 89:2603-2607. https://doi.org/10 .3168/jds.S0022-0302(06)72337-2. van Gastelen, S., B. Westerlaan, D. J. Houwers, and F. J. C. M. van Eerdenburg. 2011. A study on cow comfort and risk for lameness and mastitis in relation to different types of bedding materials. J. Dairy Sci. 94:4878-4888. https://doi.org/10.3168/jds.2010-4019.

Vasseur, E., J. Rushen, D. B. Haley, and A. M. de Passillé. 2012. Sampling cows to assess lying time for on-farm animal welfare assessment. J. Dairy Sci. 95:4968-4977. https://doi.org/10.3168/ jds.2011-5176.

Vergara, C. F., D. Döpfer, N. B. Cook, K. V. Nordlund, J. A. A. McArt, D. V. Nydam, and G. R. Oetzel. 2014. Risk factors for postpartum problems in dairy cows: Explanatory and predictive modeling. J. Dairy Sci. 97:4127-4140. https://doi.org/10.3168/jds .2012-6440.

Villettaz Robichaud, M., J. Rushen, A. M. de Passillé, E. Vasseur, D. Haley, and D. Pellerin. 2019a. Associations between on-farm cow welfare indicators and productivity and profitability on Canadian dairies: II. On tiestall farms. J. Dairy Sci. 102:4352-4363. https:// doi.org/10.3168/jds.2018-14818.

Villettaz Robichaud, M., J. Rushen, A. M. de Passillé, E. Vasseur, K. Orsel, and D. Pellerin. 2019b. Associations between on-farm animal welfare indicators and productivity and profitability on Canadian dairies: I. On freestall farms. J. Dairy Sci. 102:4341-4351. https://doi.org/10.3168/jds.2018-14817.

Vogel, K. D., T. L. Lee, B. Feinberg, G. H. Loneragan, J. Walker, L. N. Edwards-callaway, M. G. Siemens, and D. U. Thomson. 2018. An intercontinental survey of commercial abattoirs: Preliminary data on the prevalence of advanced pre-slaughter health and welfare conditions in mature cows. Bov. Pract. 52:109-118.

von Keyserlingk, M. A. G., A. Barrientos, K. Ito, E. Galo, and D. M. Weary. 2012. Benchmarking cow comfort on North American freestall dairies: Lameness, leg injuries, lying time, facility design, and management for high-producing Holstein dairy cows. J. Dairy Sci. 95:7399-7408. https://doi.org/10.3168/jds.2012-5807.

Weigele, H. C., L. Gygax, A. Steiner, B. Wechsler, and J.-B. Burla. 2018. Moderate lameness leads to marked behavioral changes in dairy cows. J. Dairy Sci. 101:2370-2382. https://doi.org/10.3168/ jds.2017-13120.

Westin, R., A. Vaughan, A. M. de Passillé, T. J. DeVries, E. A. Pajor, D. Pellerin, J. M. Siegford, E. Vasseur, and J. Rushen. 2016. Lying times of lactating cows on dairy farms with automatic milking systems and the relation to lameness, leg lesions, and body condition score. J. Dairy Sci. 99:551-561. https://doi.org/10.3168/jds .2015-9737.

Yunta, C., I. Guasch, and A. Bach. 2012. Short communication: Lying behavior of lactating dairy cows is influenced by lameness especially around feeding time. J. Dairy Sci. 95:6546-6549. https://doi .org/10.3168/jds.2012-5670.

\section{ORCIDS}

N. B. Cook @ https://orcid.org/0000-0003-4224-1016 